\title{
Trade Unions: Relevant Out of Irrelevant? A Study on Generation's Perception in Malaysia
}

\author{
Che Supian Mohamad Nor (Corresponding author) \\ Universiti Sains Malaysia, \\ Ramesh Kumar Moona Haji Mohamed \\ Universiti Tunku Abdul Rahman
}

Charles Ramendran SPR

University Tunku Abdul Rahman

Prem Kumar Nadarajan

University Tunku Abdul Rahman

Vimala Kadiresan

Faculty of Business, Accountancy and Management, SEGi University

Kota Damansara

Received: Sep. 29, 2017 Accepted: Apr. 12, 2018 Online published: May 18, 2018

doi:10.5296/ijhrs.v8i3.11929 URL: https://doi.org/10.5296/ijhrs.v8i3.11929

\begin{abstract}
Generational differences on workforce in Malaysia have stirred the value of trade unionism. The transition from generation- $X$ to generation- $Y$ has created diverse perceptions on the relevance of being a member of a trade union. In the near future, generation- $Y$ will be the bastion of the Malaysian workforce. They will be a fundamental actor in reshaping the industrial relations ecosystem in Malaysia. In this respect, this study focused on unionized and non-unionized generation-X and $\mathrm{Y}$ employee's perception on the importance of trade unionism in the Malaysian context. Using a qualitative study, face-to-face semi-structured
\end{abstract}


interviews with targeted respondents were conducted. The findings showed that the trade union do bring contributions to employees and protect employees from unfair actions but the density of trade unions declined due to unclear information known about trade unionism among generation Y. Based on the research findings, practical implications are discussed.

Keywords: trade union, perception, industrial relations, employee relations, Generation-Y, Generation-X

\section{Introduction}

The Trade Union has had always been an effective tool for workers in dealing with their employers. However its relevance is now questionable not only in Malaysia but also throughout the world (Westerman \& Yamamura, 2007). The young generation in Malaysia does not seem so much interested in trade unionism. This phenomenon can be seen from the declining pattern of union membership. Malaysian trade unions are generally small, fragmented and regional (Kumar, Ramendran, Yacob., 2012). There are about 591 unions registered in Malaysia (Malaysia Trade Union Congress, 2014), with a very low membership.

The trade unionism in Malaysia is declining due to the adverse attitude shown by most employers despite the existence of law that protects workers' rights to unionize. This had resulted in less interest exhibited by new employees especially the generation $Y$ to join the union. The number of union membership in Malaysia decrease from 889,718 in 2012 to 889,600 in 2013 despite of increase in the number of unions from 694 in 2012 to 6962013 (refer to table 1). Trade unions in Malaysia consist of 141 unions from Government sector, 456 unions from private sector, and 99 unions from statutory body (refer to table 2). In term of industry, manufacturing has the highest numbers of trade unions i.e. 158 with membership of 97,210 in year 2013 (refer table 3).

According to Andrew Low, the secretary of Malaysian Trade Union Congress (MTUC) Sarawak Division (MTUC, 2013), there are only 3.74 percent of private sector workers are unionized, and only 2.11 percent of workers are involved with any form of collective agreements. The number of in-house unions' membership rose by only 12 percent while at the same time the number of workforce increased by 67 percent. Ramasamy (2008) stated that although the number and membership of trade unions has increased, but the rate of increase has not been in tandem with the rate of increase in the workforce. Lack of interest among workers to join the union can be attributed to the weaknesses of trade unions to create awareness among new workers as to the benefit of unionism. Other reason might be due to a tougher economic atmosphere abetted by a marked pro-employer legal environment. It gives employees an unclear impression and therefore not many of them are interested to get involved in trade unions. This situation has long been highlighted by Todd and Peetz (2001) as they argued that Malaysia's industrial relations remain firmly within the "control" rather than the "commitment" framework. Furthermore, management utilize their prerogative power on employees at the workplace, leaving very limited channels for employees to collectively bargain their needs and wants with the employers.

Westerman \& Yamamura (2007) studies revealed that, attitude and performance of employees 
have significant effect on generational differences. Alivin. \& Sverke (2000) found that different generation express differing relationship to the union movement. Baby boomers and generation $\mathrm{X}$ share the principles and mission of their unions while the younger generation $\mathrm{Y}$ expresses more instrumental union attitudes. As the issue experienced in this millennium, the question arises, "what is the perception of this new generation Y towards trade union?" So the objective of this research is to examine the generational perceptions on relevancy of trade union in Malaysia.

\section{Literature Review}

\section{The Role of the Trade Union}

In Malaysia, Trade Unions Act 1959 defined trade Union as "any association or combination of workmen or employers, being workmen whose place of work is in Peninsular Malaysia, Sabah or Sarawak, as the case may be, or employers employing workmen in Peninsular Malaysia, Sabah or Sarawak..."

A Trade Union needs to be recognized by the authority before they can involve in collective bargaining process (Trade Union Act 1959 section 2). Collective bargaining is a process of negotiation between employers and their workmen pertaining disputes related to wages, hours of work, conditions of work and other terms of employment. Union act on behalf of workers to deal with employers; this process is called as collective bargaining (Clyde, 2000).

The purposes of joining a trade union is to fight for fair treatment and champion the interests of unions' members in terms of pay and working conditions by negotiating agreement with employers. Other than that, unions may also provide legal advice, financial assistance, education facilities and other benefits to its members (Waddington, \& Whitston, 1997). Thus, trade unions can be seen as an important instrument for protecting workers' interests (Amminuddin, 2008). Trade unions are capable in championing the interests and voice up the needs of their members at the workplace. The existence of trade union at the workplace has been significant in attracting non members to be more involved, hence strengthen the trade union (Hancké, 1993).

The Trade Union should pursue their members' main goals (Andrew, 2010) such as fighting for pay hikes, precluding performance based pay scheme, and minimizing competition from non-union shops. At the same time, union must keep on growing their membership; increase the number of labor force that they represent. According to Daniele and Giacomo (2000), for a trade union to be able to influence the level of pay and condition of work in labor market, it depends greatly on the degree of unionization of an organization. In other words, the trade union derives the legitimization to represent the interest of members from a high degree of unionization. For an example, a larger degree of unionization helps to create a very strong bargaining power base of a particular trade union. This in turn helps to raise the pay and better working conditions. Basically, it helps to shift the labor market equilibrium away from the competitive outcome (Carol, 2009).

The existence of unions in the workplace may prompt the management into adopting more systematic management practices. This would in turn, enhance the ability of an organization 
in introducing new products or new processes. The Trade Union would question the management in any organizational matters except with regard to the management's prerogative clause (Ramendran, Mohamed, Nadarajan \& Rajadurai, 2013). This would make top management pay more attention to employees' need and welfare before making any decision. In short, unions can lead to more creative and better and more productive solutions in organization (Rubenstein \& Kochan, 2001).

\section{The relevant of the trade union}

Good communication between trade unions and employer is of utmost importance so as to maintain a harmonious industrial relations atmosphere. It is important for employers to have a good long term relationship with trade unions. Employers can save a lot of time and money by just consulting the trade union leader (employees' representative) to identify issues that had caused employees' dissatisfaction and amicably settle it as fast as possible. Otherwise, the employer has to meet employees individually and this will slow down the decision-making process and business progress (Bryson \& Forth, 2011). Unions create direct communication channels that quickly notify employer pertaining to employees' dissatisfaction and likewise could efficiently and effectively disseminate information from the employer to the employees (Deakin, \& Koukiadakin, 2011). Unions can also protect and improve wages of their members (Bennett \& Kaufman, 2011).

Workers are not strong on their own as individuals and often fail in negotiations with their respective employers. If anyone dares to confront their employer demanding better pay and / or better working conditions, he/she might face consequences of being blacklisted, demoted or even dismissed. However if employees voice up their demands through the union, the chances of their demands being fulfilled are greater (Amminuddin, 2008).

We have to admit that certain employers have some degree of market power in which they monopolize businesses. They are able to set wage level and control the recruitment of employees (Budd, Chi, Wang, \& Xie, (2014); Freeman, \& Medoff, 1984). In this situation, the union could function as a mediator between employers and employees by safeguarding the harmonious industrial relationship. Unions will represents workers in negotiation with the management so as to ensure workers' right are safeguarded and at the same time the employer's rights for fully committed employees will also be looked into. Unions have more experience and knowledge by providing information and advice to both parties, especially legal advice, financial support and assistance.

Workers feel more comfortable to report safety problems and violations to union in which union can help pressure employer to provide safer working environment. (Kolben, 2014). Without unions, companies would become either too paternalistic or too autocratic (Piyali, Shefali \& Ashish, 2009). According to Gill (2009), unions not only have the unique advantage of delivering independent voice that cannot be replaced by management but also a contributor to organization's competitiveness.

\section{Generational perception towards the trade union}

No one disputes the importance of trade union in industrial relations; ironically the union's 
membership in Malaysia is dwindling. Thus, the question whether generation's perceptional difference has contributed to low membership of trade union in Malaysia needs to be investigated. A few studies have been done on generational perceptions toward trade union. Alivin. \& Sverke (2000) found that the older generations share the ideology and mission of their unions while the younger generation expresses more instrumental union attitudes. Its mean that younger generation explain the differences in attitudes towards unions (Sarkar, \& Charlwood, 2014). Furåker \& Berglund (2003) revealed that the younger generation is less interested in unionization because they tend to be more individualistically oriented than older generation employees. In view of unstable job situations and negative attitudes towards collectivism, younger generations seemingly have no reason to join the union. Further, Sarkar (2012) added that the company's good treatment of the employees as a result of transparent and identifiable Human Resource Management (HRM) practices brings a change in their unionism attitudes (Eric Ng, Lam, Kumar, Ramendran \& Kadiresan (2012). As there are scarce literatures on generational perception studies, this study would contribute from the Malaysian perspectives.

\section{Research Objectives}

The objective of this research is to investigate the generational perceptions on the relevancy of the trade union in Malaysia; whether there are significant differences in perceptions among generations of workforce in Malaysia. The question whether generation's perceptional difference has contributed to low membership of trade union in Malaysia needs to be investigated.

\section{Definitions}

For this study, we need to know who are generation X and generation Y in which Main (2013) gave the following definitions:

1. Generation X - those who were born between 1962 and 1981, grown up immediately after Second World War. They are highly educated, active, balanced, and happy; family oriented and grew up with high rate of blended families.

2. Generation Y - those who were born between 1982 and 2000 has been portrayed as the next big generation. They have been described as lazy, narcissistic and prone to jump from job to job.

\section{Methodology}

Research design

The research title is "Trade unions: relevant out of irrelevant? A study on generation's perception in Malaysia", derived from a problem statement whereby questioning the dwindling union membership in Malaysia in spite of its significant contributions to the workers and country thus far. Is it due to the younger workers' perceptions of it relevancy? In order to explore this phenomenon, a qualitative study has been conducted. A semi-structured interview has been used as the primary research approach. A list of guiding questions was compiled and used as guidance so as all respondents focus on the issues of interest for this 
study. However, this list was not used for standardization; it serves as a frame for the discussions only. The interviews focusing on exploring answers for the following main questions:

(1) What is the nonunionized generation's perception on trade Union?

(2) What is the unionize generation's perception on the Trade Union movement?

(3) What is the Union leader's perception on generation differences about trade union?

\section{Types of data collected}

Both primary and secondary data were collected for the purposes of this study. One type of data was not enough to achieve the objectives of the study because of the nature of the problem. Primary data was needed in order to know the real situation on the ground. Secondary data on the other hand was required to establish the situation at hand, particularly the statistics of unions and its memberships.

Sources of the data

The primary data was collected via semi-structured interview with the 10 union officials, 10 unionized generation- $X$ employees, 10 non-unionized generation- $X$ employees, 10 unionized generation-Y employees, and 10 non-unionized generation-Y employees. The secondary data was collected from existing information on the Government Agency's official website, the trade union's publication and other relevant secondary sources.

\section{Target Population}

We have chosen employees in hotel, restaurant and bar industry as our research respondents in view of high employee turnover and low union membership among them (Mohamed, Mohd nor, Hasan, Olaganthan, Gunasekaran 2013).

\section{Sample size and sampling methods}

In total, fifty respondents (10 union officials, 10 unionized generation-X employees, 10 non-unionized generation-X employees, 10 unionized generation-Y employees, 10 non-unionized generation-Y employees) constituted the sample for this study. In qualitative research, generalization of findings is not the main intention. The main objective of qualitative research is to develop an in-depth exploration of a central phenomenon. This is best achieved by using purposeful sampling strategies (Creswell, 2009). Hence, this study adopted purposeful sampling method by way of snowball sampling procedures whereby the first respondent from each category were asked to recommend other employee for interview.

\section{Interview Results}

Most similar answers from the respondents were coded from interview questions as per below:

\section{Interview questions: Unionized employee (Generation-X)}

1. What do you know about union? 
It's a labor movement where union is a party who fights for employee's right

2. Do you have intention to join labor union; if no, explain what the reasons are?

*Not applicable (respondents already a union member).

3. What is your perception towards labor unions in a changing employee relation?

Employee rights and benefits will be safeguarded

4. How would you characterize (describe) your working relationship with your manager?

One way communication: instructions from the management need to obey

5. Where the union has the right to take up cases on behalf of the victims of discrimination, has the union actually supported these workers in employment-related cases?

Trade union always plays an effective role in settling the employee's grievances.

6. Has the union publicized the legal framework and rights arising from the new laws to its members, workers and the general public, and if so in what ways?

Trade union movement is highly systematic in assigning their task force.

Interview questions: Unionized employee (Generation-Y)

1. What do you know about union?

Aware of the trade union existence and joined it but does not really know the role of the Trade Union.

2. Do you have intention to join labor union; if no, explain what the reasons are?

*Not applicable (respondents already a union member).

3. What is your perception towards labor unions in a changing employee relation?

Equality created by employers oppose to influence of trade union in changing employee relations

4. How would you characterize (describe) your working relationship with your manager?

Employees were allowed to voice out their opinion and make decision in certain circumstances

5. Where the union has the right to take up cases on behalf of the victims of discrimination has the union actually supported these workers in employment-related cases?

It's the duty of the union to handle the cases 
6. Has the union publicized the legal framework and rights arising from the new laws among its members, workers and the general public, and if so in what ways?

Not aware of it

Interview questions: non-unionized employee (Generation-X)

1. What do you know about union?

Unclear about unionization

2. Do you have intention to join labor union; if no, explain what the reasons are?

Promoting employer employee relations oppose to employer union relations.

3. What is your perception towards labor unions in a changing employee relation?

Management support magnified

4. How would you characterize (describe) your working relationship with your manager?

Give the best performance and the manager will be nice to you.

5. Where the union has the right to take up cases on behalf of the victims of discrimination has the union actually supported these workers in employment-related cases?

Union interference will complicate the situation.

6. Has the union publicized the legal framework and rights arising from the new laws among its members, workers and the general public, and if so in what ways?

Rely on media to obtain any information.

Interview questions: non-unionized employee (Generation-Y)

1. What do you know about union?

Unaware of the union

2. Do you have intention to join labor union; if no, explain what the reasons are?

Lack of interest on joining union

3. What is your perception towards labor unions in a changing employee relation?

Lack of union officers in IT knowledge in transforming ER

4. How would you characterize (describe) your working relationship with your manager?

Expecting career advancement and equality from the employer

5. Where the union has the right to take up cases on behalf of the victims of discrimination has the union actually supported these workers in employment-related cases?

Management at their best in handling disputes and settling fairly 
6. Has the union publicized the legal framework and rights arising from the new laws among its members, workers and the general public, and if so in what ways?

Not interested at all to know about union

Interview questions: Union Officials

1. What do you know about union?

Justice cannot be overrule by the management

2. Why do you want to work for a labor union?

Patriotic in representing the employees and assisting trade union

3. What are your ideas for strengthening labor unions in a changing employee relation?

Trade union plays important role as an educator and advocator for members

4. Where the union has the right to take up cases on behalf of the victims of discrimination has the union actually supported these workers in employment-related cases?

Union representations will ensure members rights safeguarded.

5. What are the differences towards generation-X and $\mathrm{Y}$ commitment in Union?

Gen-X:-Patriotism and committed to trade union

Gen-Y:-Lack of awareness and seriousness in knowing the roles of trade union.

\section{Findings}

Based on the research questions 1; what is the non-unionize generation's perception on trade Union?

Non-unionized Employees.

Looking at non-unionize Generation-X employees' perceptions, they opined that trade unions are irrelevant as management support always exists in any circumstances. Although generation-X knew the existence of trade unions act as a protection for employees, they still did not get much information. In view of this, generation- $X$ are not interested to be a member of the union.This situation exist among the younger generation of-X compared to older generation-X who was born early 1960's. Younger generation-X believed they could please their employees by optimizing their job performance and any interferences caused by the trade union might complicate the situation in organization.

Most Generation-Y does not care about unions. They are of the opinion that the trade union is no longer important as most union officers are from older generations and lack IT skills. To them, union officers would not understand the needs and wants of their generation. The saddest thing is that they have no interest in the union and could not care less about trade 
unions. Most non-unionize Generation-Y perceived that it is not important for them to know anything about union movement.

Based on the research questions 2; what is the unionize generation's perception on the Trade Union movement?

\section{Unionize Employees.}

Generally generation-X agreed that the trade union is vital in championing the employees' rights and believe by joining union will secure their employment from discriminative acts by their employer. They mostly perceived trade unions are still relevant. From the observation, most of the unionize members are the older generation of generation- $X$ who was born in early 1960's and not many of younger generation-X (born in the late 1970s and early 1980s) among our respondents. This older generation- $X$ believes that trade union played a major role in settling the employee's grievances. This findings supported D'Art \& Turner's (2008) study in which their results indicated that a substantial majority of respondents believe that employees need the protection of strong unions. Irrespective of the respondent's occupational level, the extent of job autonomy, gender, age or political orientation, positive attitudes towards unions were consistent among the majority of employees. So the older generation-X still believed and perceived that trade union is still relevant.

Generation-Y emphasized on the duties of trade union compared to roles of trade union. For them trade union is not a necessity for them as their focus diverted towards technology advancement which disseminated by the employers. They prefer to get along with the management and maintain good relationship with them. Furthermore they believe in equality created by the employers as opposed to the influence of trade union in safeguarding their interests.

Based on the research questions 3; what is the union officials' perception on generation differences about trade union?

Union officials are the voice of the employees and representative of the employees in bringing harmonious settlement to industrial relations conflicts. They are the pillars trade union always there for the workers in any circumstances. Union officials perceived the workers at an organization that provided a good working environment for employees will get workers that are more loyal to them. These workers will not go to the union if they have issues with the management as they can directly see the management to solve it. This will stop the trade union interferences in the company's matters. Union officials perceived that generation- $\mathrm{X}$ are more patriotism and committed to trade union as compared to generation- $Y$ whom could not care less about the union.

\section{Discussion and Conclusion}

Thus far we believed that the trade union has contributed greatly to workers in Malaysia. The Trade Union has always strived to safeguard the workers' rights and protected them from any unfair treatment by their employers. Currently, the Malaysian trade union movement and direction especially in the private sectors must be re-examined to ensure its relevance 
amongst all generations. The lack of awareness about trade unions among generation-Y may be due to the failure on the union's part to promote themselves to this segment of workers. As a result, most generation-Y workers were unaware of the existence of the trade union. This finding supported Bryson (2003) studies where he stated that over one-third of non-members in unionized workplaces say they would like to join a union if asked, but over half of non-members eligible to join the union at their workplace have never been asked to join.

Some generation-Y workers were reluctant to join the trade union. They worry about being blacklisted by their employer, thus jeopardizing their chances for fast career advancement. Therefore they prefer not to join the union and just follow the instructions from company. They believe that their obedient and own effort will be appreciated by the company. Even though there were many older generations-X (year 1960 -1971) joined the trade unions but the younger generation-X $(1972$ - 1982) were like most generation-Y do not really getting into unionism.

We would suggest the Malaysian Trade Union Congress (MTUC) should play an active role in creating awareness and promoting the advantages of joining trade union to all workers either generation-X or generation-Y. This can be done by organizing awareness campaign via multi media. MTUC should enlighten the new generation of workers pertaining to the availability of labor law that clearly protecting their rights for unionization.

\section{References}

Alivin, M., \& Sverke, M. (2000). Do New Generations Imply the End of Solidarity? Swedish Unionism in the Era of Individualization. Economic and Industrial Democracy, 21, 71-95. https://doi.org/10.1177/0143831X00211004

Aminuddin, M. (21 January 2008). The Role And Responsibilities of Trade Unions: What's Changing, What's Not!

Andrew, J. C. (2010). The Effects of Teachers Unions on American Education. Cato Journal, $30(1)$.

Bennett, J. T., \& Kaufman, B. E. (2011). What do unions do? A twenty-year perspective. Transaction Books. PLACE OF PUBLICATION

Bryson, A., \& Forth, J. (2011). Trade unions (pp. 255-271). Oxford University Press. PLACE OF PUBLICATION

Budd, J. W., Chi, W., Wang, Y., \& Xie, Q. (2014). What Do Unions in China Do? Provincial-Level Evidence on Wages, Employment, Productivity, and Economic Output. Journal of Labor Research, 1-20. https://doi.org/10.1007/s12122-014-9178-4

Carol, G. (2009). Union Impact on the Effective Adoption of High Performance Work Practices. Human Resource Management Review. TAK ADA NO VOL (?)

Clyde, W. (2000). From industrial democracy to union democracy. Journal of Labor Research, 3-14. 


\section{I Macrothink}

International Journal of Human Resource Studies ISSN 2162-3058 2018, Vol. 8, No. 3

Creswell, J. W. (2009). Research Design: Qualitative, Quantitative, and Mixed Methods Approaches (3rd Edition). Sage Publications, Thousands Oak, USA.

D'Art, D., \& Turner, T. (2008). Workers and the Demand for Trade Unions in Europe: Still a

Relevant Social Force? Economic and Industrial Democracy, 29, 165. https://doi.org/10.1177/0143831X07088540

Daniele, C., \& Giacomo, C. (2000). Trade Union Membership : Theories and Evidence for Italy. Journal of Economic Behaviour and Organization and Labour Economics.

Deakin, S., \& Koukiadaki, A. (2011). Capability Theory, Employee Voice, and Corporate Restructuring: Evidence from UK Case Studies. Comp. Lab. L. \& Pol'y J., 33, 427. JOURNAL OR BOOK OR WHAT?

Eric, C. H., Lam Z. H., Kumar, R., Ramendran, C., \& Kadiresan, V. (2012). The Effectiveness of Human Resource Management Practices on Employee Retention in Institute of Higher learning: A regression analysis. International Journal of Business Research and Management, 3 .

Freeman, R. B., \& Medoff, J. L. (1984). What do unions do? Indus. \& Lab. Rel. Rev., 38, 244.

Furåker, B., \& Berglund, T. (2003), Are the Unions Still Needed? Employees' Views of their Relations to Unions and Employers. Economic and Industrial Democracy, 24(4), 573-594. https://doi.org/10.1177/0143831X030244005

Gill, C. (2009). Union impact on the effective adoption of high performance work practices.

Human Resource Management Review, 39-50.

Hancké, B. (1993). Trade union membership in Europe, 1960-1990: rediscovering local unions. British Journal of Industrial Relations, 31(4), 593-613. https://doi.org/10.1111/j.1467-8543.1993.tb00415.x

Kolben, K. (2014). Trade, Monitoring, and the ILO: Working To Improve Conditions in Cambodia's Garment Factories. Yale Human Rights and Development Journal, 7(1), 3.

Kumar, R., Ramendran, C., \& Peter Y. (2012). The Impact of Employment of Foreign Workers: Local Employability and Trade Union Roles in Malaysia. International Journal of Academic Research in Business and Social Sciences, 2, 530-541.

Main, D. (9 July 2013). Who are the millennial? LiveScience retrieved from http://www.livescience.com/ on 29 April 2014.

Malaysia Trade Union Congress. Retrieved on 2013, 27 January, from http://www.mtuc.org.my/affliates.htm\#ag

Mohamed R. K. M. H., Mohamad, N. C. S., Hasan, N. A., Olaganthan, V, Gunasekaran, Y. (2013). The Impact of an Organization's Culture towards Employees' Performance: A Study on the Frontline Hotel Employees. International Journal of Academic Research in Business and Social Sciences, 3(8). https://doi.org/10.6007/IJARBSS/v3-i8/107 


\section{Macrothink}

International Journal of Human Resource Studies

ISSN 2162-3058

2018, Vol. 8, No. 3

Piyali, G., Shefali, N., \& Ashish, G. (2009). The Changing Roles of Trade Unions in India. A Case Study of National Thermal Power Corporation (NTPC), ÜNCHAH AR. Asian Academy of Management Journal, 14(1), 37-57.

Provis, C. (1996). Unitarism, Pluralism, Interests and Values. British Journal of Industrial Relations, 34(4), 473-495. https://doi.org/10.1111/j.1467-8543.1996.tb00486.x

Ramasamy, N. (2008, January). The future of the trade union movement in Malaysia. In MTUC/American Council for Labour Solidarity National Workshop on 'MTUC-The Way Forward (pp. 21-22).

Ramendran, C. S. P. R., Mohamed, R. K. M. H., Nadarajan, P., \& Rajadurai, M. M. (2013). Excessive Job Protection By Labour Law Impedes Organization Changes: To What Extend Job Retrenchment Is A Management Prerogative? International Journal of Education and Research, 1(2).

Rubenstein, S., \& Kochan, T. (2001). Learning from Saturn: Possibilities for corporate governance and employee relations. Ithaca, NY. IS THIS FROM BOOK?

Sarkar, S., \& Charlwood, A. (2014). Do cultural differences explain differences in attitudes towards unions? Culture and attitudes towards unions among call centre workers in Britain and India. Industrial Relations Journal, 45(1), 56-76.

Sarkar, S. (2012). Determinants of employees' attitudes toward union membership in India.

Journal of World Business, 47(2), 240-250.

Todd, P., \& Peetz, D. (2001). Malaysian Industrial Relations at Century's Turn: Vision 2020 or a Spectre of the Past? The International Journal of Human Resource Management, 12(8), 1365-82. Trade Union act 1959 ... CHECK WITH APA... HOW TO REFERENCE ACT...

Waddington, J., \& Whitston, C. (1997). Why do people join unions in a period of membership decline? British Journal of Industrial Relations, 35(4), 515-546.

Westerman, J. W., \& Yamamura, J. H. (2007). Generational preferences for work environment fit: effects on employee outcomes", Career Development International, 12(2), 150 - 161.

\section{Appendix A}

Table 1. Number of Trade Union and its Membership and in Malaysia Year, 2006-Jan 2013

\begin{tabular}{lll}
\hline Year & Trade Union & Membership \\
\hline 2006 & 631 & 801,585 \\
2007 & 642 & 802,212 \\
2008 & 659 & 805,565 \\
2009 & 680 & 806,860 \\
2010 & 690 & 803,289 \\
2011 & 697 & 800,171 \\
2012 & 694 & 889,718 \\
JAN 2013 & 696 & 889,600 \\
\hline
\end{tabular}




\section{Ml Macrothink}

International Journal of Human Resource Studies

ISSN 2162-3058 2018, Vol. 8, No. 3

Source: Department of Trade Union Affairs (2013). Retrieved March 3, 2013, from http://jheks.mohr.gov.my/index.php?option=com_content\&view=article\&id=145\&Itemid=10 $1 \&$ lang=en

Table 2. Number of Trade Union By Sector in Malaysia, Jan 2013

\begin{tabular}{lll}
\hline Sector & Trade Union & Membership \\
\hline Government & 141 & 434,224 \\
Private & 456 & 377,951 \\
Statutory Body & 99 & 77,425 \\
\hline TOTAL & $\mathbf{6 9 6}$ & $\mathbf{8 8 9 , 6 0 0}$ \\
\hline
\end{tabular}

Source: Department of Trade Union Affairs (2013). Retrieved March 3, 2013, from http://jheks.mohr.gov.my/index.php?option=com_content\&view=article\&id=145\&Itemid=10 $1 \&$ lang=en

Table 3. Number of Trade Union By Industry in Malaysia, Jan 2013

\begin{tabular}{|c|c|c|c|c|}
\hline \multirow[t]{2}{*}{ INDUSTRY } & \multicolumn{2}{|l|}{2012} & \multicolumn{2}{|l|}{2013} \\
\hline & $\begin{array}{l}\text { NUMBE } \\
\mathbf{R}\end{array}$ & $\begin{array}{l}\text { MEMBERSHI } \\
\mathbf{P}\end{array}$ & $\begin{array}{l}\text { NUMBE } \\
\mathbf{R}\end{array}$ & $\begin{array}{l}\text { MEMBERSHI } \\
\mathbf{P}\end{array}$ \\
\hline Agriculture, Hunting \& Forestry & 49 & 77,965 & 49 & 77,968 \\
\hline Fishing & 3 & 1,038 & 3 & 1,038 \\
\hline Mining \& Quarrying & 3 & 961 & 3 & 961 \\
\hline Manufacturing & 158 & 97,447 & 158 & 97,210 \\
\hline Construction & 4 & 1,387 & 4 & 1,387 \\
\hline Electricity, Gas \& Water & 28 & 49,374 & 28 & 49,374 \\
\hline Wholesale, Retail Trade, Repair of & 35 & 39,831 & 35 & 39,831 \\
\hline Motor Vehicles, Motorcycles, & & & & \\
\hline $\begin{array}{l}\text { Personnel \& Household Goods } \\
\text { Hotels \& Rectaurants }\end{array}$ & & & & \\
\hline $\begin{array}{l}\text { Hotels \& Restaurants } \\
\text { Transport } \quad \text { Storage }\end{array}$ & 18 & 16,383 & 18 & 16,383 \\
\hline $\begin{array}{ll}\text { Transport, } & \text { Storage } \quad \& \\
\text { Communication } & \end{array}$ & 97 & 58,635 & 98 & 58,635 \\
\hline Financial Intermediation & 41 & 43,334 & 41 & 43,344 \\
\hline $\begin{array}{l}\text { Real Estate Renting \& Business } \\
\text { Activities }\end{array}$ & 3 & 173 & 3 & 173 \\
\hline $\begin{array}{l}\text { Public Administration \& Defense, } \\
\text { Compulsory Social Security }\end{array}$ & 113 & 119,158 & 114 & 119,308 \\
\hline Education & 57 & 316,307 & 57 & 316,276 \\
\hline Health \& Social Work & 46 & 61,082 & 46 & 61,082 \\
\hline $\begin{array}{l}\text { Other Community, Social \& } \\
\text { Personnel Service Activities }\end{array}$ & 39 & 6,633 & 39 & 6,633 \\
\hline $\begin{array}{l}\text { Private Household with Employed } \\
\text { Person }\end{array}$ & 0 & 0 & 0 & 0 \\
\hline $\begin{array}{l}\text { Ex-Territorial Organization \& } \\
\text { Bodies }\end{array}$ & 0 & 0 & 0 & 0 \\
\hline Others & 0 & 0 & 0 & 0 \\
\hline TOTAL & 694 & 889,718 & 696 & 889,600 \\
\hline
\end{tabular}

Source: Department of Trade Union Affairs (2013). Retrieved March 3, 2013, from http://jheks.mohr.gov.my/index.php?option=com_content $\&$ view=article \&id=145\&Itemid=10 $1 \&$ lang=en 
Table 4. Sample of respondents from different groups

\begin{tabular}{lll}
\hline Groups & Union / Non-union & Number \\
\hline Generation X & Non-Union & 10 \\
Generations Y & Non-Union & 10 \\
Generation X & Union & 10 \\
Generation Y & Union & 10 \\
Trade Union Officials & Union & 10 \\
\hline Total & & $\mathbf{5 0}$ \\
\hline
\end{tabular}

\section{Copyright Disclaimer}

Copyright for this article is retained by the author(s), with first publication rights granted to the journal.

This is an open-access article distributed under the terms and conditions of the Creative Commons Attribution license (http://creativecommons.org/licenses/by/4.0/). 